\title{
Comparison between Use of Antibiotics and Argentum (Ag) in Infected Wound Healing
}

\author{
Yoyos Dias Ismiarto, Fadlyansyah Farid, Farry \\ Department of Orthopaedy dan Traumatology Faculty of Medicine Universitas Padjadjaran \\ Dr. Hasan Sadikin General Hospital Bandung, Indonesia
}

\begin{abstract}
Infected wound is a common problem encountered in the field of Orthopedics. Various procedures have been applied in order to achieve the effective treatment for wound infection. However, until recently, the biomolecular responses to those remain unclear. This study aimed to compare the effectiveness of antibiotics and argentum in infected wound healing by analyzing the FGF-2 and FGF-7 expressions; fibroblasts; bacteria colonization; and wound contraction rate during the proliferation phase of wound healing. This study was performed from May to September 2016 at the Pharmacology Research Laboratory, Faculty of Medicine, Padjadjaran University. A randomized clinical laboratory experimental trial with repetitive measures was performed in male rabbits that had been wounded and inoculated by 0.5 MF Staphylococcus aureus. Sample was collected before(Day 6) and after (Day 14) the application of antibiotics and argentum. The consecutive sampling method was used to determine the two treatment groups: (I) antibiotic group and (II) argentum group. The argentum group showed higher FGF2 protein level, FGF-7 protein level, fibroblast count, and wound contraction rate with $\mathrm{p}<0.05$ when compared to the antibiotic group. The use of argentum gave excellent responses to wound repair as indicated by elevated FGF2 and FGF-7 levels; fibroblast counts; and wound contraction rate. The combination of both treatments might give synergistic responses and better results in healing infected wound. Argentum is more effective than antibiotics to increase the FGF-2 and FGF-7 levels; fibroblasts count; and wound contraction rate in the proliferative phase of infected wound healing. Antibiotics are more effective than argentum to decrease bacteria colonization.
\end{abstract}

Key words: Bacteria colonization, FGF-2 protein, FGF-7 protein, fibroblast count, wound contraction rate

\section{Perbandingan antara Penggunaan Antibiotik dan Argentum (Ag) dalam Penyembuhan Luka Terinfeksi}

\begin{abstract}
Abstrak
Luka terinfeksi sering kali kita temui dalam permasalahan di bidang orthopedi. Berbagai jenis prosedur ditemukan untuk mengurangi angka kejadian infeksi, namun belum sesuai dengan yang diharapkan. Tujuan penelitian ini adalah membandingkan efektivitas antibiotik dengan argentum dengan menilai ekspresi FGF-2, FGF-7, fibroblas dan rerata kotraksi luka saat fase proliferasi penyembuhan luka. Penelitian ini dilakukan selama bulan Juni hingga September 2017 di Laboratorium Penelitian Farmakologi Fakultas Kedokteran Universitas Padjadjaran. Dilakukan pada kelinci jantan yang telah terluka dan diinokulasi oleh Staphylococcus aureus sebanyak 0,5 MF. Sampel diambil hari ke-6 dan ke-14 aplikasi antibiotik dan argentum. Dengan metode sampling berurutan di tiap-tiap kelompok perlakuan: (I) kelompok antibiotik; dan (II) kelompok argentum. Kelompok Argentum menunjukkan tingkat protein FGF-2, protein FGF-7, jumlah fibroblas dan tingkat kontraksi luka yang lebih tinggi dengan $\mathrm{p}<0,05$ dibanding dengan kelompok Ab. Penggunaan argentum memberikan respons yang sangat baik terhadap perbaikan luka seperti yang ditunjukkan oleh peningkatan kadar FGF-2, FGF-7, jumlah fibroblast, dan tingkat kontraksi luka. Kombinasi kedua pengobatan mungkin memberikan respon sinergis dan memberikan hasil yang lebih baik dalam penyembuhan luka yang terinfeksi. Argentum lebih efektif daripada antibiotik untuk meningkatkan kadar FGF-2 dan FGF-7, jumlah fibroblas, dan tingkat kontraksi luka dalam fase proliferatif dari penyembuhan luka yang terinfeksi. Antibiotik lebih efektif daripada argentum untuk menurunkan kolonisasi bakteri.
\end{abstract}

Kata kunci: FGF-2 protein, FGF-7 protein, hitung fibroblast, kolonisasi bakteri ,rata-rata penyembuhan luka

Corresponding Author: Yoyos D. Ismiarto, Department of Orthopaedy dan Traumatology Faculty of Medicine Universitas Padjadjaran/Dr. Hasan Sadikin General Hospital Bandung, Jalan Pasteur No. 38 Bandung 40161 West Java, Indonesia, Email: yosismiarto@yahoo.com 


\section{Introduction}

Infected open wounds are a complication that often occurs in the fields of orthopedics and traumatology. Infected wounds usually accompany open fractures, amputation surgery, and other postoperative wounds with secondary infections. This complication occurs in approximately $16-50 \%$ of all cases of open wounds. At Dr. Hasan Sadikin General Hospital (Rumah Sakit Dr. Hasan Sadikin, RSHS) Bandung, the incidence of infected wounds after surgery of Gustilo Anderson IIIB and IIIC open fractures is $22.7 \%$. These cases involve infection by aerobic bacteria, especially Staphylococcus aureus. ${ }^{1-4}$

Open wounds that are infected are very difficult to cure even though debridement and systemic antibiotics have been performed due to the degree of injury and bacterial resistance to antibiotics through the formation of a biofilm consisting of polysaccharide extracellular matrix in the form of glycocalyx which protects bacteria. Various attempts have already been made to eliminate bacterial resistance, including the use of Argentum (Ag). ${ }^{1,4-6}$

Argentum is a topical antiseptic that effectively reduces the number of organisms that cause infections in wounds. Argentum also rarely causes resistance. In an in vitro experiment, Argentum is found to be effective in penetrating biofilms bound to microbial cell proteoglycans. Argentum is not dangerous for mammals because mammalian cells contain less proteoglycans. ${ }^{7.8}$

Although Argentum produces good results in healing infected wounds, the trigerred biomolecular response is still not fully understood. In addition, there is no clear evidence of the effect of the application of Argentum on changes in levels of FGF-2 and FGF-7 proteins, the number of Staphylococcus aureus colonies, fibroblast counts, and wound contraction rate after treatment compared to before treatment.

The aim of this study was to compare the effectiveness of antibiotics and Argentum against infected wounds as measured by analyzing the levels of FGF-2 protein, FGF-7 protein, fibroblast count, bacterial colonies, and wound contraction rates in the proliferation phase of infected wound healing.

\section{Methods}

This was an experimental study with random samples and repeated measurements which aimed to determine the effectiveness of antibiotics and Argentum against infected wounds by analyzing FGF-2 and FGF-7 protein levels;fibroblast counts; bacterial colonies; and wound contraction ratesin the proliferation phase of wound healing. This study was conducted at the Medical Research Unit Laboratory, Faculty of Medicine, Universitas Padjadjaran and Laboratory of Pharmacology and Therapeutic, Faculty of Medicine, Universitas Padjadjaran during the months of May-September 2016. Ethical clearance was issued by the Health Research Ethics Committee, Faculty of Medicine, Universitas Padjadjaran/RSHS.

Subjects consisted of 20 male rabbits aged more than 3 months, weighed 3-4 kgs, and had wounds with a colony of Staphylococcus aureus of more than 1x105 colonies/gram units. After adapting to the laboratory enclosure environment (H1), rabbits were wounded and inoculated with $0.5 \mathrm{MF}$ Staphylococcus aureus bacteria, covered with moist gauze $(0.9 \%$ $\mathrm{NaCl}$ ) fixed with plaster and replaced every 24 hours. Observation was performed for 5 days (incubation period of Staphylococcus aureus infection). Rabbits were excluded if an infection occurs during the adaptation period before bacterial inoculation and if the number of bacterial colonies at the initial examination (H5) is less than $1 \times 105$ colonies/gram units. Subjects were divided into two groups: antibiotic group (I) and Argentum (II) group with a treatment duration of 8 days (H7-H14). Sampling were performed before treatment (H6) and after treatment (H14).

In the antibiotic group (I), cefazolin antibiotics was administered at a dose of $30 \mathrm{mg} /$ $\mathrm{kgBW} /$ day divided into two and was injected intramuscularly to the thigh muscle. Antibiotics was injected to the right and left thighs alternately. Infected wounds are covered with moist gauze $(0.9 \% \mathrm{NaCl})$ which was fixed with tape and replaced every 24 hours.

In the Argentum (II) group, a sheet of Argentum nanoparticles was placed on the surface of the infected wound then covered with moist gauze $(0.9 \% \mathrm{NaCl})$ fixed with plaster and replaced every 24 hours.

For retrieving specimen for examination, the wound were cleaned first with physiological saline $(0.9 \% \mathrm{NaCl})$ and let stand for \pm 10 minutes and then pressed slowly so that the fluid under the skin can be obtained properly. For wound base tissue, a sterile curette was used to retrieved sample. The tissue was then placed into a sterile tube. 
To measure the FGF-2 and FGF-7 protein levels, reagents were prepared first. All reagents should reach room temperature and be mixed before being used. Mixed reagents were then put into eight tubes that were placed in a frame for inspection. Tube 0 was added with $100 \mu \mathrm{L}$ standard buffer solution while the tube provided for chromogen was left blank. A standard solution of $100 \mu \mathrm{L}$ was added to the appropriate microtiter tube, then $50 \mu \mathrm{L}$ standard buffer solution followed by $50 \mu \mathrm{L}$ sample was added. The side of the plate should be tapped to mix the solution. After it is mixed, the plate was closed with a cover and incubated for 2 hours in room temperature. The mixture in the tubes was and the liquid was disposed. The tube was then washed 4 times and $100 \mu \mathrm{L}$ of Biotinylated anti-FGF-b was added to each tube except for the chromogen blank tube. The side of the plate was tapped to mix and the plate was covered and incubated for 1 hour at room temperature. Afterwards,the mixture of tubes was aspirated and liquid was disposed. The tube was then washed 4 times and $100 \mu \mathrm{L}$ of Streptavidin-HRP solution was added to each tube except for the chromogen blank tube. The plate was then covered and incubated for 30 minutes at room temperature. Next, the mixture in the tubes was aspirated and liquid was disposed. The tube was then washed 4 times and $100 \mu \mathrm{L}$ of Chromogen stabilization was added to each tube and the liquid in the tube turned blue. Incubation was then performed for 30 minutes in room temperature in the dark. After the incubation time was reached, a 100 $\mu \mathrm{L}$ stop solution was added and the plate was tapped on the side to mix. The solution changed color from blue to yellow. The plate was read after 2 hours of addition of the stopping solution and the concentration of FGF $(\mathrm{pg} / \mathrm{mL})$ was read from the sample and control.

Tissue histological preparations were made for examining the number of fibroblasts. The wound tissue samples were collected and the fixation process was carried out using 10\% formalin solution in the form of buffer for 1218 hours. The washing process was performed using flowing water for 1.5 hours to remove the remaining fixation agent. The process of decalization was performed using $50 \%$ formic acid made of $500 \mathrm{ml}$ formic acid dissolved in 500 $\mathrm{ml}$ sterile aquadest for $24-48$ hours. It was then followed by the washing process using running water for 1.5 hours to remove the remaining decalcified material. Dehydration was then perfomed using multilevel concentrations of alcohol, i.e. $70 \%$ concentration for +15 minutes,
$80 \%$ alcohol for 1 hour, $95 \%$ alcohol for 2 hours, $95 \%$ alcohol for 1 hour, and $100 \%$ alcohol for 3 hours. This step was followed with the clearing process using xylol 3 times for 1 hour, 2 hours, and 2 hours, respectively. The infiltration process of embedding material in tissue was done using liquid paraffin at a temperature of $560-600{ }^{\circ} \mathrm{C}$. This was done 3 times, each for 2 hours. The tissue was then embedded in parafin and the material was prepared bu cutting the paraffin blocks using microtomes and hematoxillin-eosin was used to dye the tissue preparation.

The number of fibroblast was counted by using a binocular microscope with 1000x magnification and graticulae ocular placed inside the microscope lens.The number of fibroblast cells was counted in the graticulae box in three visual fields of each preparation. The average number from the three visual fields was then calculated in cells $/ \mu \mathrm{L}$ unit. These data were then analyzed statistically. The Staphylococcus aureus bacteria was counted by dilutingthe Staphylococcus aureus bacteria from sample liquid with physiological $\mathrm{NaCl}$ liquid to $1 / 10,1 / 100$, and $1 / 1000$. Each diluted sample was then poured into Nutrient Agar media which hasd been heated to $40-45{ }^{\circ} \mathrm{C}$ until a homogeneous mixture was formed. This mixture was then poured into a sterile petri dish while shaking the dish carefully to make sure that the mixture was evenly distributed to the bottom of the petri dish. This was then letstand for 30 minutes until the agar was hardened and the dish was then placed into a $37^{\circ} \mathrm{C}$ incubator for 24 hours. The number of colonies of Staphylococcus aureus bacteria was counted using a microscope with a counting chamber to see the number of Staphylococcus aureus bacteria. The formula used for calculation of colony was colonies $\mathrm{x}$ dilutions in units of cfu/gram. These data were then analyzed statistically.

The Wound Contraction Rate was measured by first placing a transparent plastic sheet on the wound. On the sheet, outermost wound boundary was drawn to match the wound pattern. This results in an representative image of the wound on the sheet which was then processed using Adobe Photoshop program to determine the area of the wound in $\mathrm{mm}^{2}$ units. The obtained wound contraction measurement data were then tabulated and analyzed to understand the ongoing wound healing.

For statistical analysis of the data, SPSS version 21 was used. Data were analyzed by performing normality tests, homogeneity tests, paired $t$ tests, variation analysis (ANOVA), 
Kruskal-Wallis test, correlation analysis, and regression analysis.

\section{Results}

During the study period, 20 rabbits with the same age and weight were subjected to the study. The bacterial colonies in the infected wounds had a homogeneous characteristics.

Both groups showed ncreased levels of FGF2 and FGF-7 as well as increased fibroblasts count after treatment. The number of bacterial colonies decreased in both groups while an increase in the wound contraction rate was seen after treatment in both groups. All changes occurred in H14 (after treatment) compared to H6 (before treatment) and were statistically significant $(\mathrm{p}<0.05)$.

The use of Argentum presented better results in increasing the FGF-2 level $(27.36 \pm 1.52 \mathrm{pg} /$
mL vs. 20.88 $\pm 2.28 \mathrm{pg} / \mathrm{mL})(\mathrm{p}<0.05)$ as well as better in increasing the FGF-7 level $(32.93 \pm 1.44$ pg/mL vs. $31.95 \pm 2.48 \mathrm{pg} / \mathrm{mL})(\mathrm{p}<0.05)$ when compared to the antibiotic group. This group also had better results in increasing the fibroblast counts $(6.28 \pm 2.63$ cell $/ \mu \mathrm{L}$ vs. $5.25 \pm 1.03$ cell/ $\mu \mathrm{L})(\mathrm{p}<0.05)$, and wound contraction rate $\left(1.26 \pm 0.42 \mathrm{~mm}^{2} /\right.$ week vs $1.25 \pm 0.67 \mathrm{~mm}^{2} /$ week) $(\mathrm{p}<0.05)$ when compared to the antibiotic group. However, in decreasing the number of bacterial colonies antibiotics showed better results compared to Argentum $(121.87 \pm 50.73 \mathrm{cfu} /$ gram vs. $168.37 \pm 14.13 \mathrm{cfu} /$ gram $)(\mathrm{p}<0.05)$.

A positive correlation between FGF-2 levels $(r=0.71, p \leq 0.00), F G F-7$ levels $(r=0.63, p \leq 0.00)$, fibroblast count $(r=0.715, p \leq 0.00)$, the number of colonies $(r=-0.67, p \leq 0.00)$, and the wound contraction rate was found in $\mathrm{H} 14$, meaning that the increase in FGF-2 level, FGF-7 level, and fibroblast count as well as the decreased number of bacterial colonies on day 14 were

Table-1 Levels of FGF-2. FGF-7. Fibroblast Count. Bacterial Colonies. and Wound Contraction Rate in the Antibiotic Group

\begin{tabular}{|c|c|c|c|}
\hline \multirow[b]{2}{*}{ Variable } & \multicolumn{2}{|c|}{ Sample } & \multirow[b]{2}{*}{ p-value } \\
\hline & $\begin{array}{c}\text { H6 } \\
n=10\end{array}$ & $\begin{array}{c}H 14 \\
n=10\end{array}$ & \\
\hline FGF-2 & & & $0.04^{* *}$ \\
\hline Mean \pm STD & $16.27 \pm 1.88$ & $20.88 \pm 2.28$ & \\
\hline Median & 15.70 & 21.45 & \\
\hline Range (min-max) & $14.20-19.10$ & $17.60-23.60$ & \\
\hline FGF-7 & & & $0.00^{* *}$ \\
\hline Mean \pm STD & $17.26 \pm 3.29$ & $31.95 \pm 2.48$ & \\
\hline Median & 17.35 & 31.90 & \\
\hline Range (min-max) & $12.80-21.50$ & $29.20-35.30$ & \\
\hline Fibroblast Count & & & $0.00^{* *}$ \\
\hline Mean \pm STD & $3.31 \pm 1.09$ & $5.25 \pm 1.03$ & \\
\hline Median & 4.00 & 5.00 & \\
\hline Range (min-max) & $2.00-6.00$ & $4.00-6.00$ & \\
\hline Bacterial Colonies & & & $0.00^{* *}$ \\
\hline Mean \pm STD & $243.12 \pm 29.29$ & $121.87 \pm 50.73$ & \\
\hline Median & 240.50 & 122.75 & \\
\hline Range (min-max) & $200.00-298.00$ & $23.73-194.00$ & \\
\hline Wound Contraction Rate & & & $0.00^{* *}$ \\
\hline Mean \pm STD & $0.76 \pm 0.46$ & $1.25 \pm 0.67$ & \\
\hline Median & 0.72 & 1.11 & \\
\hline Range (min-max) & $0.07-1.94$ & $0.09-2.63$ & \\
\hline
\end{tabular}

Significancy based on $\mathrm{p}<0.05 ;{ }^{* *}$ shows significancy statistically; H6: day 6. H14: day 14 
Table-2 Levels of FGF-2, FGF-7, Fibroblast Count, Bacterial Colonies, and Wound Contraction Rate in the Argentum Group

\begin{tabular}{|c|c|c|c|}
\hline \multirow[b]{2}{*}{ Variable } & \multicolumn{2}{|c|}{ Sample } & \multirow[b]{2}{*}{ p-value } \\
\hline & $\begin{array}{c}\mathrm{H6} \\
\mathrm{n}=10\end{array}$ & $\begin{array}{c}\mathrm{H} 14 \\
\mathrm{n}=10\end{array}$ & \\
\hline FGF-2 & & & $0,01^{* *}$ \\
\hline Mean \pm STD & $17.97 \pm 2.15$ & $27.36 \pm 1.52$ & \\
\hline Median & 18.90 & 27.45 & \\
\hline Range (min-max) & $14.10-19.90$ & $25.30-29.70$ & \\
\hline FGF-7 & & & $0,00^{* *}$ \\
\hline Mean \pm STD & $18.62 \pm 1.42$ & $32.93 \pm 1.44$ & \\
\hline Median & 18.55 & 33.25 & \\
\hline Range (min-max) & $16.40-20.40$ & $30.20-34.50$ & \\
\hline Fibroblast Count & & & $0,01^{* *}$ \\
\hline Mean \pm STD & $3.25 \pm 1.03$ & $6.28 \pm 2.63$ & \\
\hline Median & 4.00 & 6.00 & \\
\hline Range (min-max) & $2.00-4.00$ & $2.00-8.00$ & \\
\hline Bacterial Colonies & & & $0,00^{* *}$ \\
\hline Mean \pm STD & $270.12 \pm 5.98$ & $168.37 \pm 14.13$ & \\
\hline Median & 272.10 & 170.00 & \\
\hline Range (min-max) & $260.10-277.80$ & $145.00-185.00$ & \\
\hline Wound contraction rate & & & $0,00^{* *}$ \\
\hline Mean \pm STD & $1.03 \pm 0.65$ & $1.26 \pm 0.42$ & \\
\hline Median & 1.11 & 1.41 & \\
\hline Range (min-max) & $0.16-1.94$ & $0.50-1.75$ & \\
\hline
\end{tabular}

Significancy based on $\mathrm{p}<0.05$;** show statistical significance; H6: day 6. H14: day 14

associated with better wound healing, which was characterized by an increase in the wound contraction rate.

There was a strong functional relationship between infected wounds healing and the increase in FGF-2 level (r2=0.514), FGF-7 level ( $\mathrm{r} 2=0.403)$, and fibroblast count $(\mathrm{r} 2=0.511)$ as well as the decreased bacterial colonies (r2= $0.458)$.

\section{Discussion}

Wound healing is divided into several phases: inflammation, proliferation, and remodeling. Some mediators and essential growth factors, such as FGF-2 and FGF-7, are released from the beginning of the inflammatory process and play important roles in the process of wound healing through extensive mitogenic abilities and also in regulating target cell differentiation and migration. In the proliferation phase, granulation tissue appears. This network consists of fibroblasts and inflammatory cells along with newly formed blood vessels. Fibroblast migration and proliferation into the wound are supported by cytokines such as FGF-2 and FGF7. Bacterial infections can interfere with the epithelization process so that it can prolong the inflammatory phase and slow down the wound healing process. ${ }^{9-11}$

In this study, all groups were inoculated with Staphylococcus aureus bacteria before the study. This bacterium is a gram-positive bacterium that commonly infects open wounds. Cefazolin was chosen in this study because it is an effective broad-spectrum antibiotic to eliminate grampositive bacteria. This antibiotic works by inhibiting cell wall synthesis, causing bacterial death. In this study, the number of bacterial 
colonies was reduced sharply after cefazolin administration, which is in agreement with the existing literature. ${ }^{12-14}$ In addition, there were also increased levels of FGF-2 and FGF-7 after eradication of bacteria using cefazolin. This is because eradication of bacteria will shorten the inflammatory phase and accelerates wound healing process by shifting into the proliferation phase so it will improve the overall wound healing process. ${ }^{8,10,16,17}$

Argentum is a topical antiseptic that effectively kills organisms that contaminate and infect wounds while rarely cause resistance. Argentum effectively penetrates biofilms formed by bacteria and binds to proteoglycans on bacterial cell walls. Argentum causes bacterial cell proteins to denaturate, disrupts bacterial metabolism, and blocks bacterial growth by damaging the bacterial DNA. Argentum will activate proteolytic enzymes in bacteria that cause necrosis or damage to bacterial cell membranes. In addition, through the nucleation mechanism, Argentum will form an Argentum nanoparticle solution that the ratio between surface area and volume is greater and this will optimize the dissipation of Argentum. This agent is also more stable to hot temperatures and is not toxic. $6,18,19$

In this study, the use of argentum gave inferior results when compared to antibiotics in terms of decreasing the number of bacterial colonies. However, argentum provides a better response to increase the levels of FGF-2, FGF7 , andfibroblast count as well as increasing the wound contraction rate. This can be achieved because Argentum can stimulate an increase in $\alpha$-SMA expression on the surface of the fibroblast which can stimulate contraction of the extracellular matrix. ${ }^{20}$

In conclusion, argentum is more effective than antibiotics in healing infected wounds as shown by increased levels of FGF-2, FGF-7, and fibroblast count as well as increased wound contraction rate. Nevertheless, antibiotics is more effective in reducing the number of bacterial colonies than Argentum.

\section{References}

1. Siegel HJ. Management of open wounds: lessons from orthopedic oncology. Orthop Clin North Am. 2014;45(1):99-107.

2. Vazquez J. The emerging problem of infectious diseases: The impact of antimicrobial resistance in wound care.
Wounds: a compendium of clinical research and practice. 1-9. Wounds: a compendium of clinical research and practice (WOUNDS). 2006;1-17.

3. Childs SG. Biofilm: the pathogenesis of slime glycocalyx. Orthop Nurs. 2008;27(6):361-9.

4. Bjarnsholt $\mathrm{T}$. The role of bacterial biofilms in chronic infections. APMIS Suppl. 2013; (136):1-51.

5. Balakatounis KC, Angoules AG. Low-intensity electrical stimulation in wound healing: review of the efficacy of externally applied currents resembling the current of injury. Eplasty. 2008;8:e28.

6. Moore RA, Liedl DA, Jenkins S, Andrews KL. Using a silver-coated polymeric substrate for the management of chronic ulcerations: the initial Mayo Clinic experience. Adv Skin Wound Care. 2008;21(11):517-20.

7. Thakral G, Lafontaine J, Najafi B, Talal TK, Kim P, Lavery LA. Electrical stimulation to accelerate wound healing. Diabet Foot Ankle. 2013;4:1-104.

8. Mian M, Aloisi R, Benetti D, Rosini S, Fantozzi R. Role of heterologous collagen (biopad) in the tissue repair process of wounds in rat. Argentum Med LLC. 2007;1:1-3.

9. Sinno H, Prakash S. Complements and the wound healing cascade: an updated review. Plastic Surgery International. 2013;2013:17.

10. Kim MH, Liu W, Borjesson DL, Curry FR, Miller LS, Cheung AL, et al. Dynamics of neutrophil infiltration during cutaneous wound healing and infection using fluorescence imaging. J Invest Dermatol. 2008;128(7):1812-20.

11. Werner S, Grose R. Regulation of wound healing by growth factors and cytokines. Physiol Rev. 2003;83(3):835-70.

12. Monge Jodra V, Sainz de Los Terreros Soler L, Diaz-Agero Perez C, Saa Requejo CM, Plana Farras N. Excess length of stay attributable to surgical site infection following hip replacement: a nested casecontrol study. Infect Control Hosp Epidemiol. 2006;27(12):1299-303.

13. Cosgrove SE. The relationship between antimicrobial resistance and patient outcomes: mortality, length of hospital stay, and health care costs. Clin Infect Dis. 2006;42 (Suppl 2):S82-9.

14. Kirkland KB, Briggs JP, Trivette SL, Wilkinson WE, Sexton DJ. The impact of surgicalsite infections in the 1990s: attributable mortality, excess length of hospitalization, and extra costs. Infect Control Hosp 
Epidemiol. 1999;20(11):725-30.

15. Jain JG, Housman ST, Nicolau DP. Humanized tissue pharmacodynamics of cefazolin against commonly isolated pathogens in skin and skin structure infections. J Antimicrob Chemother. 2014;69(9):2443-7.

16. Shimoaka T, Ogasawara T, Yonamine A, Chikazu D, Kawano H, Nakamura $\mathrm{K}$ et al. Regulation of osteoblast, chondrocyte, and osteoclast functions by fibroblast growth factor (FGF)-18 in comparison with FGF-2 and FGF-10. J Biol Chem. 2002;277(9):7493500.

17. Harris LG, Foster SJ, Richards RG. An introduction to Staphylococcus aureus, and techniques for identifying and quantifying S. aureus adhesins in relation to adhesion to biomaterials: review. Eur Cell Mater. 2002;4: 39-60.

18. Jaafar SE. Wound healing as well as fibroblast and neutrophil numbers in a skin expoed to infrared and electrical stimulation. Journal of Kirkuk University-Scientific Studies. 2011;6(2):50-61.

19. Chao PG, Lu HH, Hung CT, Nicoll SB, Bulinski JC. Effects of applied dc electric field on ligament fibroblast migration and wound healing. Connective Tissue Res. 2007;48: 188-97.

20. Mehmandoust FG, Torkaman G, Firoozabadi M, Talebi G. Anodal and cathodal pulsed electrical stimulation on skin wound healing in guinea pigs. J Rehabil Res Dev. 2007;44(4):611-8. 